\title{
United States security cooperation with Kenya in the second decade of the 21st century
}

\begin{abstract}
The subject of the paper is the cooperation of the United States with Kenya in the area of security in the second decade of the 21 st century. The introduction contains the methodological assumptions of the paper and a synthetic historical background. The first section of the paper covers the theoretical framework. The second section outlines the increase of the United States' strategic involvement in Africa, including East Africa, in the 21st century. The third section discusses the joint efforts of the US and Kenya in combating terrorism and piracy. The fourth section is devoted to US training and development assistance for the Kenyan security sector. The considerations are carried out within the framework of the postcolonial current of the theory of international relations. During the research, the method of analyzing text sources was used. The main thesis of the paper assumes that although Africa, including Kenya, was not a particularly important area of strategic interest of the United States, these countries had significant common security interests and undertook cooperation to implement them. First of all, it concerned counteracting international terrorism, but also the general stabilization of East Africa. In the future, the importance of East Africa in American politics might systematically increase, both in the area of economy and security, which will entail further strengthening of cooperation between the US and Kenya.
\end{abstract}

Key words: United States, Kenya, security, terrorism, development assistance

\section{Introduction}

D uring the Cold War, relations between the United States and Kenya can be justified within the global East-West paradigm. Kenya's regional security threats had been integrated into US regional and global interests. This was associated with Western activities in East Africa, with the 1953 US acquisition of Kagnew base in Asmara, Ethiopia, and the 1964 British-Kenya mutual defence pacts (Adar, 1995, p. 101). Both the United States and the Soviet Union were interested in the Horn of Africa, mainly due to the strategic location in the Middle East neighborhood and the possibility of affecting oil supplies. Kenyan neighbors, including Uganda, Somalia and Ethiopia, switched sides in the Cold War rivalry, depending on which political party ruled. United States military support for Kenya began in 1976 and was based upon American concerns about the threat posed to Kenya by its neighbors, who collaborated on an ad hoc basis with the USSR. In 1980, states signed an agreement allowing US aircraft and ships access to Kenyan airports and ports. This was to facilitate American troops operating in the Indian Ocean basin, including the Persian Gulf. When the United States gained greater access to the installations of the Gulf States in the 1990s, the strategic importance of Kenya decreased. Nevertheless, the US continued to use Kenyan territory to carry out humanitarian aid for East Africa and Central Africa (Kenya - US Relations). 
After the Cold War, Kenya became one of the fronts in the war against international terrorism under US leadership. On 7 August 1998 truck bombs hit the US embassies in Nairobi, Kenya and Dar es Salaam, Tanzania. Incomparably more deadly Nairobi blast killed 212 people of which twelve were Americans. This was the first time al-Qaeda directly attacked Americans (Friedman, 2009, p. 219). Osama bin Laden publicly praised the suicide bombers for their courage and for managing "to rid the Islamic nation of disgrace" (Patman, 2016, p. 26). The attacks caused retaliation by the Bill Clinton administration in the form of cruise missile strikes in Sudan and in Afghanistan, in which the organization had its bases and training camps. Al-Qaeda leaders hoped that the US military response would increase anti-American sentiment among Muslim communities and deepen antagonisms between the Western and Islamic world (Gardner, 2016, p. 145). In the 21 st century, the issue of the global war on terror dominated relations between the United States and Kenya.

The aim of the paper is to analyze and evaluate the cooperation of the United States with Kenya in the field of security in the second decade of the 21 st century. The considerations are carried out within the framework of the postcolonial current of the theory of international relations. During the research, the method of analyzing text sources was used. The main research problem lies in the question of whether the United States shared important security interests with Kenya and whether it measurably supported the partner in their implementation. The main thesis of the paper assumes that although Africa, including Kenya, was not a particularly important area of strategic interest of the United States, these countries had important common security interests and undertook joint actions to implement them. First of all, it concerned counteracting international terrorism, but also the general stabilization of the East African region. In the future, the importance of East Africa, including Kenya, in the policy of the United States should systematically increase, both in the area of economy and security, which will entail further strengthening of cooperation between the US and Kenya.

\section{Theoretical framework}

The research problem will be considered from the perspective of postcolonial theory. In the 21 st century, there have been several fundamental changes in the theory of international relations. Above all, researchers have moved beyond the "great debates" between dominant paradigms, including between realism and idealism, between classical and behavioralist approaches, and between positivists and post-positivists. Secondly, interest in metatheories has been declining in favor of medium-range theories. Thirdly, there has been an increase in the importance of the theory of constructivism, which, despite attempts to go beyond the privileges of the West, to a large extent has still remained a Western-centered undertaking. Fourth, although the Western perspective is dominant, there is a growing conviction that in the theory of international relations it is necessary to take more decisive account of the perspective of the Global South (Acharya, Buzan, 2017, pp. 343-348).

The postcolonial current was established as an independent research approach in the mid-1980s. The pioneers of postcolonial studies should be considered Jean-Paul Sartre, 
Franz Fanon and Edward Said, who defined themselves as representatives of the postcolonial current. Some works by leaders of anti-colonial movements, including Mahatma Gandhi, Leopold Senghor and Kwame Nkrumah, is also qualify for the postcolonial canon. In the 21st century, Gayatri Spivak, Homi Bhabha and Walter D. Mignolo may be recognized as the best-known representatives of the academic community participating in the postcolonial discourse (Polus, 2014, pp. 113-114).

The term "postcolonial" is ambiguous and defined in various ways. However, it mostly concerns the period after the colonial peak so describes its aftermath. The term is often used to signify a position against imperialism and Eurocentrism. In last decades postcolonial studies has developed because postcolonial critique allows for a wide-ranging investigation into power relations in various contexts (Bahri).

From the perspective of the postcolonial current contemporary violence in Africa is explained by traditional security studies in terms of a lack of institutions and attributes associated with western modernity, such as sovereignty, rather than as a consequence of long-lasting colonial and postcolonial relationship with the West. The savagery and mass murder accompanying conflicts in various parts of Africa are attributed to nonWestern factors, such as political, economic and social underdevelopment, or peculiarities of local ethnic identities, as in the "new barbarism" thesis (Barkawi, Laffey, 2006, pp. 342-347). It is often overlooked that the main influence on the formation of Third World states was the global balance of power. Moreover, conflicts between global powers have been invariably transferred to the weaker states dependent on them. Besides, the formation of dependent countries is to a large extent a consequence of the international norms created by superpowers that define effective and legitimate statehood. This is completed by interventions, including military interventions, by the global powers to enforce these standards by weaker states. All of this significantly affects the level of conflicts both between and within Third World countries (Ayoob, 2002, p. 45).

Mohammed Ayoob describes the security relationship between great powers and Third World states as subaltern realism. According to him the subaltern position of dependent states is the result of the aforementioned processes influencing the formation of postcolonial states, their colonial and postcolonial exploitation and also regional and internal conflicts. Subaltern states can improve their position by improving the governance and strengthening state institutions. Anyway, Ayoob is opposed to the symbiosis of security and emancipation, considering it a manifestation of neocolonialism (Ayoob, 1995 , p. 5). He believes that the emancipation process can only be carried out by the strong against the weak, so its causative factor is in principle the West (Czaputowicz, 2012, pp. 212-213).

\section{Increase of the US strategic engagement in Africa and East Africa in the 21 st century}

After the end of the Cold War, the United States intervened several times in Africa, including in 1990 and 1997 in Liberia, in 1992-1994 in Somalia, in 1998 in Sudan and 2011 in Libya (Hansen, 2011, p. 63). East Africa remained an unstable region, in which there were a number of armed conflicts, including internal conflicts in Somalia, Eritrea, 
Rwanda, Sudan and South Sudan, as well as interstate ones like Eritrea with Ethiopia or Sudan with South Sudan. These conflicts not only destabilize East Africa, but also to some extent affect global security by generating terrorism, organized crime, piracy, refugee movements, and disruptions to trade, including oil imports (Kienscherf, 2013, p. 130). Much of these conflicts were a consequence of the state-building of the colonial powers, disregarding ethnic and religious divisions.

At the beginning of the 21 st century American development assistance was only slightly associated with the level of economic and social development of states. Wealthy Israel had been receiving much more than all of Sub-Saharan Africa, which is extremely poor. Focusing on strategic premises when choosing recipients of aid was criticized both in the United States and internationally (Cameron, 2005, p. 52). A significant part of the assistance was constituted by military support, which was primarily addressed to Israel and Egypt. This means that the US was primarily focused on pursuing its own strategic interests in the post-colonial world.

In the 21st century, the United States strengthened its strategic position in Africa. During the presidency of George W. Bush, two major military installations were launched. In 2002, the United States established a base in Djibouti for the Combined Joint Task Force - Horn of Africa (CJTF-HOA). The base increases the US strategic access to East Africa and the Middle East. The base in Djibouti is the only permanent military base of the US Armed Forces in Africa. From Camp Lemonnier, in which about 4,000 soldiers are stationed, Americans are controlling operations in neighboring destabilized areas of Somalia and Yemen, including the waters of the Horn of Africa (Cheng, 2018). In addition to the Camp Lemonnier in Djibouti, the United States has base access agreements with several African states, including Kenya (Kieh, 2014, p. 171). Especially useful for the CJTF-HOA are military bases in Djibouti, Kenya and Ethiopia, this is why the US directed funds for their modernization (van Apeldoorn, de Graaff, 2016, p. 202).

The second major military installation is the United States Africa Command (AFRICOM) opened in 2007 in Stuttgart, Germany. The Command is intended, inter alia, to help increase the military capabilities of African partners and to support them in maintaining peace and security. AFRICOM coordinates a series of exercises and training carried out by American soldiers in many African countries. During the George W. Bush administration, the United States implemented two major counterterrorism programs in Africa: the Trans-Sahara Counterterrorism Initiative and the East African Counterterrorism Initiative. Under these programs, the US Army helps to develop counter-terrorism capabilities of troops from selected African states, including Kenya. African soldiers trained by Americans are to serve as 'foot soldiers' for the US's war on terror (Kieh, 2014, p. 171). Military cooperation with East African states made it easier for the United States to respond to emerging threats with supra-regional implications. This was to facilitate the United States' role as a global hegemon.

During the presidential campaign, Barack Obama criticized George W. Bush for the militarization of US foreign policy. In practice, however, during his presidency this trend towards Africa was maintained. Weapons sales to Africa grew, as did partner army training and strengthening AFRICOM (Kieh, 2014, p. 175). President Obama maintained bases in East Africa, North Africa and the Arabian Peninsula, and placed in them Ameri- 
can drones carrying out combar missions, including in Somalia, Yemen, Libya and Syria (Fuller, 2017, p. 137).

The 2015 US National Security Strategy emphasizes increased engagement with Africa, partly to counter the prevalence of weak and failing states (Taylor, 2017, p. 33). However, Barack Obama wanted to limit the involvement of the US Armed Forces in military missions in Africa. This required shifting the burden of action to allies and partners (David, 2016, p. 54). Moreover, to limit the threat to American soldiers his administration maximized the use of technological innovations like drones (Holland, 2017, p. 50).

One of the pillars of President Obama's policy towards Africa was the peaceful resolution of armed conflicts. This, in turn, was supposed to strengthen other key goals, including strengthening the rule of law, economic development and improving public health (Pagel, 2009). President Obama was in favor of upgrading civilian capacity in international operations and achieving better integration of defence, development and diplomacy (Aaronson, 2014, p. 131). Initially his successor Donald Trump was less interested in African affairs, focusing primarily on the combating of international terrorism. Since 2019, the importance of Africa for its administration has increased, mainly to curb China's growing influence. The intensifying global economic, political and, to a limited extent, military rivalry makes Africa, including East Africa, an important strategic area for the United States.

\section{Cooperation between the US and Kenya in combating terrorism and piracy}

Kenya is surrounded by countries where armed conflicts have been ongoing for years, including Somalia and South Sudan, which generate a number of threats and destabilize the region. Kenya faces a number of security issues, such as terrosism, piracy, religious extremism, ethnic violence, political violence, bandits, poaching, wildlife trafficking, and cattle rustling. In the security area, US support to Kenya focuses on cooperating to fight radicalism, terrorism, piracy, insecurity, and to foster peace and stability in East Africa (Kenya - US Relations). US support for Kenya is much broader in nature, and includes a general strengthening of state sovereignty and improving state governance. In the context of the subaltern realism, it is therefore a manifestation of the emancipation of the weaker state by the stronger.

Kenya is a strategic partner of the United States in the implementation of counterterrorism initiatives in East Africa and the Horn of Africa. The main threat is Al-Shabab, established in 2006 terrorist organization and Islamist jihadist insurgent group originating from Somalia, which main goal is to establish an Islamic state (Felter, Masters, Sergie, 2020). Al-Shabab, or "the Youth," controls significant rural areas of Somalia, and also periodically controlled main cities, including the capital, Mogadishu. The African Union Mission to Somalia (AMISOM), however, pushed its fighters out of larger population centers. Al-Shabab still poses a huge threat to civilians, Somali security forces and international forces. Al-Shabab has many sources of financing, including piracy, ransom, smuggling, illegal taxes and extortion of local businesses, farmers, and humanitarian organizations. Kenyan soldiers were also involved in the cooperation with Al-Shabab in smuggling sugar (The Economist, 2015). 
At least since 2009 Al-Shabab has been cooperating with an international terrorist network of al-Qaeda, to witch it pledged allegiance in 2012. Osama bin Laden urged the Somalis to overthrow the government and intensify jihad. Al-Qaeda's plan assumed spreading instability from Somalia to neighboring countries, including Kenya, and paralysing of sea trade routes. In July 2009, the US Department of State (DoS) issued a revised advisory to US citizens traveling to Kenya, warning against the terrorist threat and violent crime. In September 2009, the US conducted a successful operation to kill senior al-Queda official in Somalia. After that, the Kenyan government decided to strengthen patrols on the border with Somalia and raise security standards in urban centers (Chau, 2010, pp. 143-144). In Somalia also operates Islamic State (IS), as Islamic State in Somalia (ISS). It is also trying to expand its influence to other East African countries, mainly Kenya and Ethiopia. IS has for years tried to convince al-Shabab to switch allegiances, indicating similarity of goals and better operational capabilities than al-Qaeda (Meleagrou-Hitchens, 2015). An alliance with al-Shabab also wants to establish Iran that supports international terrorism and is hostile to the US.

The Kenyan branch of al-Shabab is commonly known as al-Hijra. It reports to headquarters in Somalia, where many fighters train. Its goal in Kenya is to establish Islamic rule in northeastern border region and at the coast (Central Intelligence Agency). Al-Shabab and al-Hijra are particularly active in the northeastern part of the country, inhabited mostly by Kenyan Somalis. However, their fighters conduct attacks also in the depths of Kenya. The bloodiest terrorist attacks took place in September 2013 on upscale Westgate shopping mall in Nairobi, in April 2015 on the Garissa University College, in June 2014 at the coastal town of Mpeketoni, and in January 2020 on the upmarket office and hotel complex in Nairobi. Each of these attacks killed from several dozen to over a hundred people, including American citizens. Al-Shabab fighters also carried out fatal attacks on Kenyan bases in Somalia, including in January 2016 on base in el-Ade, and in January 2017 on base in Kulbiyow. Al-Shabab also attacks US troops stationed in Somalia, and for the first time in January 2020 launched a small arms attack on the Manda Bay US base in Kenya. Cumulatively between 2010 and 2019 al-Shabab killed between 4,000 and 10,000 people, most in Somalia, but over 600 people in Kenya. Several times more people were injured (Maruf, 2020).

Washington sees Kenya as a key ally in a joint military campaign against al-Shabab in Somalia. In October 2011, the Kenya Defence Forces (KDF) entered Somalia. In February 2012 they joined the AMISOM, reaching in 2017 over 3,600 soldiers. Compared to other African contingents, Kenyan soldiers entered Somalia well-equipped, but they had no experience in this type of operation. In late $2012 \mathrm{KDF}$ took control over the strategic port city of Kismayo, which served as one of al-Shabab's key sources of revenue, and in 2014 over several other al-Shabab strongholds (Specialist in African Affairs, 2015, pp. 10-11). US-Kenya cooperation in combating terrorism has included: sharing intelligence; supplying of equipment for KDF; training Kenyan security personnel in the US; and other logistic and training support (Muluvi, Odhiambo, Otieno, 2015). American air strikes are also playing an increasingly important role. Between 2007 and 2014, there were several of them each year, in 2015 - 11, in 2017 - 35, and in 2019 - 59 (Felter, Masters, Sergie, 2020). Kenya also participated in the controversial American Extraordinary Rendition (ER) program. 
Another serious threat to Kenya and to some extent the US is sea piracy in the Horn of Africa. The significance of these waters results from passing strategic sea routes through which, among others, Middle East oil is transported. The Gulf of Aden which is on the way to the Mediterranean Sea is of major importance. Somali pirates attack ships to force a ransom, which can reach even tens of millions of dollars. Profits are invested, for example, in the Kenyan real estate market (Aaltola, Käpylä, Vuorisalo, 2016, pp. 154). In the case of the Kenyan coast, it is particularly important to ensure access to ports, including Mombasa, which is the gateway to East African markets. For the United States, securing sea trade routes, including oil supplies, is crucial in the context of maintaining its dominant economic position in the world. The United States played an important role in anti-piracy operations at the Horn of Africa - "Allied Provider" and "Allied Protector " in 2008, and "Ocean Shield" between 2009 and 2016. The US Navy, after Indian Navy, was the largest contributor of ships to anti-piracy operations in the region. A serious problem in combating piracy is the lack of jurisdiction of Somali courts over detained pirates. The US and Kenya have an agreement to transfer of suspected pirates captured by the US Navy to Kenya for prosecution (Specialist in African Affairs, 2015, p. 11).

\section{US training and development assistance for the Kenyan security sector}

The United States supports Kenya's security sector because it treats the partner as an important stabilizing factor for the entire region. For this reason it has four security assistance objectives in Kenya: professionalize the Kenyan military forces; increase Kenyan counterterrorism and border security capabilities; increase maritime security awareness; and improve peacekeeping capabilities (U.S. Relations...).

The US Armed Forces use Kenyan territory as a training ground and a starting point for military missions in the region. American soldiers are stationed at the Camp Simba US naval base, due to the location commonly known as Manda Bay military base, located $450 \mathrm{~km}$ east of Nairobi, on the coast of the Indian Ocean. American soldiers train at the base, and they train Kenyan soldiers to fight against Somali terrorists. Base airport is used to patrol the activities of al-Shabab and carrying out bombings.

In the first year of President Barack Obama's office, several initiatives were taken in the field of security cooperation between the US and Kenya. In April 2009, the US Department of Energy's National Nuclear Safety Administration signed an agreement with Kenyan government for the installation of radiation detection equipment in the port of Mombasa, as well as training and technical support in this area. This made it possible to scan freight containers for nuclear materials and radioactive substances. In June 2009, the US-supported maritime center of excellence was opened at Bandari Maritime Academy in Mombasa. The center is intended for training military and civilians in the field of maritime security. The training program was developed in cooperation with the US Naval War College. In August 2009, creation of the Kenya Army Ranger Strike Force was announced with the support of the US. Kenyan soldiers recruited to this unit are trained to conduct rapid response operations, including counterterrorism (Chau, 2010, pp. 143-144).

During Barack Obama's presidency, Kenya was one of the largest recipients of US security assistance in Africa. For security purposes, it received annually around $\$ 40$ mil- 
lion from the US Department of Defense (DOD) and the US Department of State, but there were years with significantly higher support. For example, within "train-and-equip" counterterrorism assistance, the value of assistance in 2013 was over \$20 million, but in 2015 over $\$ 80$ million. This increase was due to the implementation of the US Administration's new Counterterrorism Partnerships Fund (CTPF). This support was mainly intended to secure the border with Somalia and support Kenya's military involvement in AMISOM. Kenya was largest beneficiary of the State Department Anti-Terrorism Assistance (ATA) in Africa which strengthens border and coastal protection, law enforcement, and counterterrorist capabilities. Kenyan Armed Forces also has received assistance through the State Department's Foreign Military Financing (FMF) program, and through regional programs like the Global Peacekeeping Operations Initiative (GPOI) and the Partnership for Regional East Africa Counterterrorism (PREACT). This is worth to mention that Kenyan purchases through the Foreign Military Sales (FMS) program were sizable by regional standards, and have included fighter aircraft, helicopters, and Air Force computer systems (Specialist in African Affairs, 2015, p. 15).

DOD allocated funds to counternarcotics assistance for Kenya, for example from 2013 to 2015 it was \$2 million. International Narcotics Control and Law Enforcement (INCLE) financially supports a number of programs in Kenya in the area of rule of law, including police reforms. The US has supported Kenyan police in different ways. An example was support for the Independent Police Oversight Authority, which plays a special role in the fight against police corruption and political crime (Specialist in African Affairs, 2015, pp. 11-12, 15).

The visits to Kenya of Secretary of State John Kerry in May 2015 and President Barack Obama in July 2015 provided opportunities for talks on security issues. They emphasized the role of Kenya in peace process in East Africa and in antiterrorist coalition (Specialist in African Affairs, 2015, p. 1). The same year the Security Governance Initiative (SGI) was established, which supports the US in managing the security sectors of six African countries - Kenya, Ghana, Mali, Niger, Nigeria, and Tunisia (Muluvi, Odhiambo, Otieno, 2015). In Kenya SGI focuses on border management, improvement of police services and administration of justice, as well as fighting violence extremism (Mutambo, 2020).

The United States supported Kenyan refugee camps for Somalis and South Sudanese. In 2015 Kenya hosted about 590,000 refugees, most of them in the Dadaab / Alinjugur refugee complex (almost 350,000 refugees) near the Somali border, and in Kakuma (more than 184,000 refugees) near the border with South Sudan (Specialist in African Affairs, 2015 , p. 10). In 2019, there were approximately 490,000 refugees in Kenya, including over 264,000 Somali and 122,000 South Sudanese (United States Agency for International Development, 2020). The US used Kenya's ports and airports to carry out humanitarian missions in Africa, including Rwanda, Congo, Sudan, South Sudan and Somalia.

During the meeting in the White House at the end of August 2018, presidents Donald Trump and Uhuru Kenyatta decided to establish a Strategic Partnership between countries. It was to be a cornerstone of peace, stability and good governance in Africa and the Indian Ocean region. Parties reaffirmed and strengthened their commitment to counterterrorism cooperation. In addition to regular security consultations, they decided to deepen their cooperation in the field of security and defence in practice. The US has 
assured of a further contribution to enhance Kenya Defence Forces capabilities based on US military equipment. American president also made a promise to strengthen Kenya's national disaster and crisis response capacity (Joint Statement..., 2018). During the ceremony, President Trump appreciated the dedication of the KDF in combatting al-Shabab and Islamic State in Somalia and thanked Kenya for its diplomatic efforts to establish peace in Somalia and South Sudan.

In May 2019 in Washington, Kenyan Foreign Minister Monica Juma and US Deputy Secretary of State John Sullivan signed the Bilateral Strategic Dialogue (BSD) framework and the Security Governance Joint Country Action Plan, that outline plans to raise bilateral relations to what a US diplomat called "a new level." The ministers announced the deepening of military and civilian security cooperation and increased American support in these areas. (Kelley, 2019) The joint statement stated that "Both sides committed to enhance counterterrorism, defence, and maritime surveillance security cooperation through intelligence sharing and capacity building." Ministers also discussed the possibility of American companies implementing projects to upgrade the country's emergency communications systems (Kiplagat, 2019).

\section{Conclusion}

The United States, unlike its European allies, was not the dominant colonial power in Africa. American commitment to the security of Africa is therefore not a result of assuming historical responsibility, but of pursuing its own interests as a hegemon. In the last decade, Africa, including Kenya, was not a particularly important area of strategic interest of the US. Nevertheless, the US and Kenya had important common security interests and undertook joint actions to implement them. It mainly concerned counteracting international terrorism, but more broadly general stabilization of East Africa. Over the past decade, Kenya has received relatively considerable support from the US in the field of security. This was due to the US perception of Kenya as a stabilizing factor in East Africa and important partner in strengthening security in the region. However, US support for Kenya was much broader and covered areas other than security. According to the subaltern realism, it was an attempt by the US to emancipate Kenya and drawn it into cooperation with the West.

Due to demographic and economic development, the interest of the United States in Africa will increase. Kenya is the gateway to East Africa, which is importnt region of the continent. The historical and cultural connections of Kenya with the West, the traditions of cooperation in the field of security, and the dynamically developing economy of Kenya makes it the natural partner of the US. China's economic expansion in Africa, the deepening rivalry for energy resources and the increase in global tensions between the superpowers mean that the United States will try to strengthen its position on the continent, including in East Africa. Stable Kenya can make this process easier for Americans, so the US should support its security sector. However, the United States must be careful because Kenya does not want to be a place of proxy war between superpowers. Moreover, the Kenyan authorities and society must be treated as real partners, not subjects of neocolonial politics. 


\section{Bibliography}

Aaltola M., Käpylä J., Vuorisalo V. (2016), The Challenge of Global Commons and Flows for US Power. The Perils of Missing the Human Domain, Routledge, London-New York.

Aaronson M. (2014), Interventionism in US foreign policy from Bush to Obama, in: Obama's foreign policy. Ending the War on Terror, eds. M. Bentley, J. Holland, Routledge, London-New York.

Acharya A., Buzan B. (2017), Why is there no Non-Western International Relations Theory? Ten years on, "International Relations of the Asia-Pacific", vol. 17.

Adar K. G. (1995), Kenya-US Relations: A Recapitulation of the Patterns of Paradigmatic Conceptualization, 1960s-1990s, in: The United States and Africa: From Independence to the End of the Cold War, eds. M. Munene, J. D. O. Nyunya, K. G. Adar, East African Educational Publishers Ltd., Nairobi.

Apeldoorn B. van, Graaff N. de (2016), American Grand Strategy and Corporate Elite Networks. The Open Door since the end of the Cold War, Routledge, London-New York.

Ayoob M. (1995), The Third World Security Predicament: State Making, Regional Conflict, and the International System, Lynne Rienner Publishers, Boulder.

Ayoob M. (2002), Inequality and Theorizing in International Relations: The Case for Subaltern Realizm, "International Studies Review", vol. 4, no. 3.

Bahri D. About Postcolonial Studies, ScholarBlogs, https://scholarblogs.emory.edu/postcolonialstudies/about-postcolonial-studies/, 11.10.2020.

Barkawi T., Laffey M. (2006), The postcolonial moment in security studies, "Review of International Studies", vol. 32.

Cameron F. (2005), US Foreign Policy after the Cold War. Global hegemon or reluctant sheriff? Second edition, Routledge, London-New York.

Chau D. C. (2010), Global Security Watch-Kenya, PRAEGER, Santa Barbara.

Cheng A. (2018), Will Djibouti Become Latest Country to Fall Into China's Debt Trap?, "Foreign Policy", https://foreignpolicy.com/2018/07/31/will-djibouti-become-latest-country-to-fall-into-chinas-debt-trap/, 15.10.2020.

Central Intelligence Agency, The World Factbook. Kenya, CIA, https://www.cia.gov/library/publications/the-world-factbook/geos/ke.html, 11.10.2020.

Czaputowicz J. (2012), Bezpieczeństwo międzynarodowe: wspótczesne koncepcje, Wydawnictwo Naukowe PWN, Warszawa 2012.

David S. (2016), Obama: the reluctant realist, in: US Foreign Policy and Global Standing in the 21st Century. Realities and perceptions, eds. E. Inbar, J. Rynhold, Routledge, London-New York.

Felter C., Masters J., Sergie M. A. (2020), Al-Shabab, Council on Foreign Relations, https://www.cfr. org/backgrounder/al-shabab, 15.10.2020.

Friedman B. H. (2009), Perception and power in counterterrorism: assessing the American response to Al Qaeda before September 11, in: American Foreign Policy and the Politics of Fear Threat inflation since 9/11, eds. A. T. Thrall, J. K. Cramer, Routledge, London-New York.

Fuller Ch. (2017), The assassin in chief: Obama's drone legacy, in: The Obama Doctrine. A legacy of continuity in US foreign policy?, eds. M. Bentley, J. Holland, Routledge, London-New York.

Gardner H. (2016), American Global Strategy and the "War on Terrorism”, Routledge, London-New York.

Hansen B. (2011), Unipolarity and World Politics. A theory and its implications, Routledge, LondonNew York.

Holland J. (2017), Obama as modern Jeffersonian, in: The Obama Doctrine. A legacy of continuity in US foreign policy?, eds. M. Bentley, J. Holland, Routledge, London-New York. 
Joint Statement from President Donald J. Trump and President Uhuru Kenyatta (2018), The White House, https://www.whitehouse.gov/briefings-statements/joint-statement-president-donald-jtrump-president-uhuru-kenyatta/, 15.10.2020.

Kelley K. J. (2019), Kenya among our strongest world partners, US official says, "Nation", https:// www.nation.co.ke/news/Kenya-US-relations-up-a-new-level/1056-5105224-10i6ibxz/index. html, 18.10.2020.

Kenya - US Relations, GlobalSecurity, https://www.globalsecurity.org/military/world/kenya/forrel-us. $\mathrm{htm}, 15.10 .2020$.

Kieh G. K. Jr. (2014), The Obama administration's policy toward Africa, in: Obama and the World. New directions in US foreign policy. Second edition, eds. I. Parmar, L. B. Miller, M. Ledwidge, Routledge, London-New York.

Kienscherf M. (2013), US Domestic and International Regimes of Security. Pacifying the globe, securing the homeland, Routledge, London-New York.

Kiplagat S. (2019), Kenya and U.S. Make Joint Pledge to 'Degrade'Al-Shabaab, "All Africa”, https:// allafrica.com/stories/201905090607.html, 18.10.2020.

Maruf H. (2020), Al-Shabab Attacks Killed 4,000 in Past Decade, Says Data-Gathering Group, VOA, https://www.voanews.com/africa/al-shabab-attacks-killed-4000-past-decade-says-data-gathering-group, 18.10.2020.

Meleagrou-Hitchens A. (2015), Terrorist Tug-of-War. ISIS and al Qaeda Struggle for al Shabab's Soul, "Foreign Affairs", https://www.foreignaffairs.com/articles/kenya/2015-10-08/terrorist-tugwar, 15.10.2020.

Muluvi A., Odhiambo P., Otieno M. (2015), Deepening Kenya-U.S. relations: Prospects for President Obama's visit to Kenya, Brookings.edu, https://www.brookings.edu/blog/africa-in-focus/2015/07/24/deepening-kenya-u-s-relations-prospects-for-president-obamas-visit-to-kenya/, 18.10.2020.

Mutambo A. (2020), Kenya seeks to forge close security ties with US, "Nation", https://www.nation. co.ke/news/Kenya-seeks-to-forge-close-security-ties-with-US/1056-5103438-c4klptz/index. html, 18.10.2020.

Pagel Ch. (2009), Obama Ghana Speech: FULL TEXT, HuffPost, https://www.huffpost.com/entry/ obama-ghana-speech-full-t_n_230009?guccounter=1, 15.10.2020.

Patman R. G. (2016), Globalization, the Post-Cold War Era, and Visions of US Leadership, in: The Bush Leadership, the Power of Ideas, and the War on Terror, eds. D. B. Macdonald, D. Nabers, R. G. Patman, Routledge, London-New York.

Polus A. (2014), Postkolonialna teoria stosunków międzynarodowych, in: Stosunki Międzynarodowe. Wokół zagadnień teoretycznych, ed. K. Kącka, Wydawnictwo Naukowe Uniwersytetu Mikołaja Kopernika, Toruń.

Specialist in African Affairs (2015), Congressional Research Service Report. U.S.-Kenya Relations: Current Political and Security Issues, EveryCRSReport, https://www.everycrsreport.com/ files/20150723_R42967_5dddfa027dbd8d43e3f4b090e7904236fdffe1d7.pdf, 11.10.2020.

Taylor W. A. (2017), US national security strategy and threats, in: The Future of US Warfare, eds. S. N. Romaniuk, F. Grice, Routledge, London-New York.

The Economist (2015), The Kenyan army is accused of running a sugar-smuggling racket with Somali terrorists, "The Economist", https://www.economist.com/middle-east-and-africa/2015/11/23/ the-kenyan-army-is-accused-of-running-a-sugar-smuggling-racket-with-somali-terrorists, 18.10.2020.

United States Agency for International Development (2020), Food Assistance Fact Sheet Kenya, USAID, https://www.usaid.gov/sites/default/files/documents/1866/FFP_Fact_Sheet_Kenya.pdf, 15.10.2020.

U.S. Relations With Kenya, US Department of State, https://www.state.gov/u-s-relations-with-kenya/, 15.10.2020. 


\section{Współpraca Stanów Zjednoczonych z Kenią w obszarze bezpieczeństwa w drugiej dekadzie XXI wieku}

\section{Streszczenie}

Tematem artykułu jest współpraca Stanów Zjednoczonych z Kenią w obszarze bezpieczeństwa w drugiej dekadzie XXI wieku. We wprowadzeniu przedstawiono założenia metodologiczne artykułu oraz syntetyczne tło historyczne. Pierwsza część artykułu obejmuje ramy teoretyczne. Druga część przedstawia wzrost strategicznego zaangażowania Stanów Zjednoczonych w Afryce, w tym w Afryce Wschodniej, w XXI wieku. W trzeciej części omówiono wspólne wysiłki Stanów Zjednoczonych i Kenii w walce z terroryzmem i piractwem. Czwarta część poświęcona jest szkoleniom i pomocy rozwojowej dla kenijskiego sektora bezpieczeństwa. Rozważania prowadzone są w ramach postkolonialnego nurtu teorii stosunków międzynarodowych. Podczas badań skorzystano z metody analizy źródeł tekstowych. Główna teza artykułu zakłada, że chociaż Afryka, w tym Kenia, nie były szczególnie ważnymi obszarami strategicznego zainteresowania Stanów Zjednoczonych, to kraje te miały istotne wspólne interesy bezpieczeństwa i podejmowały współpracę w celu ich realizacji. Przede wszystkim dotyczyło to przeciwdziałania międzynarodowemu terroryzmowi, ale także ogólnej stabilizacji Afryki Wschodniej. W przyszłości znaczenie Afryki Wschodniej w polityce amerykańskiej powinno systematycznie rosnąć, zarówno w sferze gospodarczej, jak i bezpieczeństwa, co pociągnie za sobą dalsze zacieśnianie współpracy między USA a Kenią.

Słowa kluczowe: Stany Zjednoczone, Kenia, bezpieczeństwo, terroryzm, pomoc rozwojowa 